\title{
Liquid Phase Selective Hydrogenation of Citral over Bimetallic Transition Metal Catalysts
}

\author{
S A Ananthan (Corresponding author) \\ Department of Inorganic chemistry, School of Chemical Sciences \\ University of Madras, Guindy Campus, Chennai 600025, India \\ Tel: 91-944-463-8299Ｅ-mail: saananth2@yahoo.com \\ V Narayanan \\ Department of Inorganic chemistry, School of Chemical Sciences \\ University of Madras, Guindy Campus, Chennai 600025, India \\ Tel: 91-944-429-9226_E-mail: vnnara@yahoo.co.in
}

Received: September 26, 2010 Accepted: October 19, 2010 doi:10.5539/ijc.v3n2p55

\begin{abstract}
Silica supported bimetallic catalysts of $\mathrm{Co}-\mathrm{Ni}, \mathrm{Ni}-\mathrm{Cu}$ and $\mathrm{Cu}-\mathrm{Co}$ were prepared by deposition precipitation method, calcined at two different temperatures $475^{\circ} \mathrm{C}$ and $675^{\circ} \mathrm{C}$. The prepared catalysts were characterized by BET surface area, SEM, EDX, FT-IR, thermogravimetry and XRD techniques. The XRD measurement of $\mathrm{Ni}-\mathrm{Cu} / \mathrm{SiO}_{2}$ catalyst has peaks due to $\mathrm{CuO}$ and $\mathrm{NiO}$ oxides. The catalytic activity and selectivity of these prepared catalysts towards liquid phase selective hydrogenation were studied. Amongst the studied catalysts, $\mathrm{Co}-\mathrm{Ni} / \mathrm{SiO}_{2}$ cacined at $475^{\circ} \mathrm{C}$ had presented higher selectivity in terms of citral towards unsaturated alcohols (geraniol and nerol) in a isopropanol solvent medium and $0.2 \%$ catalyst loading, at $90^{\circ} \mathrm{C}$ temperatures under 4 bar pressure with $750 \mathrm{rpm}$ agitation.
\end{abstract}

Keywords: Silica support, Bimetallic catalysts, XRD, SEM, FTIR, Citral, Selective hydrogenation, Unsaturated alcohols

\section{Introduction}

The liquid phase selective hydrogenation of unsaturated $\alpha, \beta$ - aldehydes to the corresponding unsaturated alcohols are an important step in the synthesis of various fine chemicals. An unsaturated alcohol is a very particular important intermediate in several industries such as flavour, fragrance and pharmaceutical industries (Gallezot \&, Richard, 1998; Bartok \& Molnar, 1997; Smith \& Notheisz, 1999; Sheldon-Bekkum 2001). Application of heterogeneous catalysts has been increasing because of the virtues of easy separation from the organic media and catalyst reusability, which facilitate the use of continuous process and development of environmental friendly processes. However, this is still a challenge as the reduction of the $\mathrm{C}=\mathrm{C}$ bond is thermodynamically favoured in comparison with that of the $\mathrm{C}=\mathrm{O}$ bond. Citral hydrogenation reaction of fine chemical industry Fig. 1 illustrates the main products obtained in this reaction. A lot of studies have been carried out with both catalysts (homogeneous and heterogeneous) in order to obtain results of industrial interest (Malathi \& Viswanath, 2001; Lashdaf, Lahtinen, Lindblad, Venalainen \& Krause, 2004; Zhu, Liu, Jaenicke \& Chuah, 2004). It is known that the choice of the adequate catalyst plays an important role in the activity and selectivity of these reactions. The nature of the active metal, its particle size, supports (Singh, \& Vannice, 2000; Lashdaf, Hase, Kauppinen, \& Krause, 1988) and the additions of promoters (Bachiller-Baeza, Rodriguez-Ramos \& Guerrero-Ruiz, 2001) are some examples of factors that exert influence on the performance of the catalyst. Other parameters like the solvent used have also been taken into consideration (Maki-Arvela, Tiainen, Neyestanaki, Sjoholm, Rantankyla, Laine, Salmil, \& Murzin, 2002; Burgener, Ferrer, Mallat \& Baiker, 2004; Neri, Mercadante, Donato, Visco, \& Galvagno, 1994). Several studies have been carried out employing different active metals and we can conclude that selectivity is towards unsaturated alcohols.

The process of citronellal can be obtained with palladium (Burgener, Wirz, Mallat \& Baiker, 2004) nickel (Tiainen, Maki-Arvela \& Salmi, 1999; Baijun, Lianhai, Bingchun, Tianxi \& Iwatani, 1998) and nickel alloys 
(Lee \& Chen, 1999; Luo \& Zhuang, 2001) Osmium (Singh \& Vannice, 2001) and rhodium give rise to the unsaturated alcohols while with the use of platinum and ruthenium the selectivity could be modified by the addition of a second metal (Asedegbega-Nieto, Bachiller-Baeza, Guerrero-Ruiz \& Rodriguez-Ramos, 2006; Mali-Arvela, Tiainen, Lindblad, Kumar, Sjoholm, Ollonqvist, Vayrnen, Salmi \& Murzin, 2003; Richard, Ockelford, Giroir-Fendler \& Gallezot, 1989; Galvagno, Milone, Donato, Neri \& Pietropaolo, 1993; Galvagno, Donato, Neri \& Pietropaolo,1989). As for the citral hydrogenation, bimetallic catalysts can also improve selectivity towards unsaturated alcohol, when compared to monometallic catalyst, due to electronic and geometric effects (Fouilloux, 1988). Silica supported bimetallic catalysts are very interesting materials in general terms, since one metal can fine tune or modify the catalytic properties of the other metal as a result of both structural and electronic effects. Therefore, bimetallic catalysts usually improve both activity and selectivity and even stability of the catalysts (Ponec, 2001).

In the field of hydrogenation, bimetallic catalysts are most often used in order to improve selectivity and stability of the single component metal catalysts (Savargaonkar, Khanra, Pruski, \& King, 1996; Coq \& Figueras, 2001). The catalytic performance of bimetallic catalysts differ significantly from that of the individual components; often show mutual promotion effects towards reduction and increasing thermal stability against sintering (Kulkarni, Sankar \& Rao, 1991). Bimetallic catalysts supported on high specific surface area carriers, such as silica and alumina, have attracted considerable attention recently because of their better performance when compared to the corresponding monometallic counterparts (Ponec, 2001). Additionally, the preparation of supported bimetallic catalysts by different methods could lead to catalysts with new characteristics, where a specific interaction between the two metals could produce a hybrid catalyst whose behavior may differ significantly from that of the catalysts prepared by conventional methods.

In the present study, a series of transition metal-based bimetallic $\mathrm{Co}-\mathrm{Ni} / \mathrm{SiO}{ }_{2} ; \mathrm{Ni}-\mathrm{Cu} / \mathrm{SiO}_{2} ; \mathrm{Cu}-\mathrm{Co} / \mathrm{SiO}_{2}$ catalysts have been prepared by deposition precipitation method, calcined at low $\left(475^{\circ} \mathrm{C}\right)$ and high $\left(675^{\circ} \mathrm{C}\right)$ temperatures. The catalysts have been characterized by various techniques like, Brunauer-Emmett-Teller (BET) surface area, Scanning electron microscopy (SEM), EDX, FT-IR and X-ray Diffraction (XRD). The catalytic activity and selectivity of these bimetallic catalysts were evaluated for liquid phase selective hydrogenation of citral to unsaturated alcohol (geraniol and nerol) in an isopropanol medium under condition of temperatures range $60-110^{\circ} \mathrm{C}, 1$ to 6 bar pressures and 0.1 to 0.3 catalyst loads.

\section{Experimental}

\subsection{Preparation of Catalysts}

Various bimetallic catalysts of $\mathrm{Co}-\mathrm{Ni} / \mathrm{SiO}_{2} ; \quad \mathrm{Ni}-\mathrm{Cu} / \mathrm{SiO}_{2}$ and $\mathrm{Cu}-\mathrm{Co} / \mathrm{SiO}_{2}$ were prepared by deposition-precipitation method. Bimetals were deposited over silica support in 1:1 molar ratio (based on metals) keeping the loading amount constant at $20 \mathrm{wt} . \%$ with respect to $\mathrm{SiO}_{2}$. In a typical preparation procedure, the required quantities of the respective metal nitrate salts (Fluka, AR Grade) were dissolved separately in double distilled water and mixed together. To this mixture solution, the required quantity of colloidal silica (40 wt. \%, Fluka, AR Grade) was added and the resultant slurry was stirred for $4 \mathrm{~h}$ to obtain homogeneous mixture. Subsequently, the homogenized slurry was titrated with aqueous ammonia until $\mathrm{pH}=8.5$. Thus formed precipitated gel was filtered, washed several times until free from anion impurities and dried at $120^{\circ} \mathrm{C}$ for $16 \mathrm{~h}$. The oven-dried sample was finally calcined at $475^{\circ} \mathrm{C}$ for $4 \mathrm{~h}$ in air atmosphere. A small portion of the finished catalyst was further heated at $675^{\circ} \mathrm{C}$ for 4 hours to evaluate thermal stability.

\subsection{Characterization of Catalysts}

The BET surface area measurements were made on a Micromeritics Gemini 2360 instrument by $\mathrm{N}_{2}$ adsorption at liquid nitrogen temperature. Prior to measurements, samples were oven dried at $120^{\circ} \mathrm{C}$ for $12 \mathrm{~h}$ and flushed with argon gas for 2 hours.

Scanning electron microscopy (SEM) analyses were carried out with a Jeol JSM 5410 microscope, operating with an accelerating voltage of $15 \mathrm{kV}$. Micrographs were taken after coating by gold sputtering. Elemental analysis was carried out on a Kevex, Sigma KS3 Energy dispersive X-ray (EDX) instrument operating at a detector resolution of $136 \mathrm{eV}$. Powder X-ray diffraction (XRD) patterns have been recorded on a Siemens D-5000 diffract meter, using Ni-filtered $\mathrm{Cu} \mathrm{K}_{\alpha}(0.15418 \mathrm{~nm})$ radiation source. Crystalline phases were identified with the help of ASTM Powder Data Files. The infrared spectra were recorded on a Nicolet 740 FT-Infrared spectrometer at ambient conditions, using $\mathrm{KBr}$ disks with a normal resolution of $4 \mathrm{~cm}^{-1}$ and averaging 100 spectra. 


\subsection{Catalyst Testing}

Citral (mixture of $\mathrm{E}$ and $\mathrm{Z}$ forms, Merck, 99\%) and isopropanol (Fluka, 99.5\%) are used as received without further purification. Liquid phase citral hydrogenation experiments were performed in a stirred semi-batch reactor (model 4574, Parr Instrument Co.). Before the reaction the catalysts were reduced in situ under hydrogen (gas purity, 99.995\%) flow $\left(80-100 \mathrm{ml} / \mathrm{min}\right.$ ) for $2 \mathrm{~h}$ under 4 bars a $120^{\circ} \mathrm{C}$. Then, the reactor was cooled to reaction temperature. Reactant mixture $(200 \mathrm{ml}$ of $0.1 \mathrm{M}$ citral in a isopropanaol) was injected into the bubbling unit to remove the dissolved oxygen before it was injected into the reactor and contacted with the catalysts. Citral hydrogenation reaction was performed at $60^{\circ} \mathrm{C}$ and at a stirring speed of $750 \mathrm{rpm}$. Preliminary runs carried out at different stirring rates, loading and catalysts grain size demonstrated the absence of internal and external transfer limitations under the selected conditions. Liquid samples were periodically withdrawn through sample tube extending inside the reactor and analyzed in a HP 4890 GC furnished with an HP 5 semi-capillary column of $15 \mathrm{~m}$ and $0.53 \mathrm{~mm}$ ID. The GC analysis was performed using a flame ionization detector, using Helium gas as carrier, and the column was kept at a constant temperature, $393 \mathrm{~K}$. Under these analytical conditions, the retention time of the reported reactants and products were citral (E): 30.7; citral (Z): 35.4; nerol: 27.6; geraniol 32.2 and acetals: $41 \mathrm{~min}$. The presence of acetals was confirmed by the use of mass spectroscopy - Gas chromatography (GC MS-QP2010 Plus). From the results obtained in these analyses, information such as the catalytic activity, selectivity of the reaction and conversion could be derived.

\section{Results and discussions}

\subsection{Characterization}

The $\mathrm{N}_{2}$ BET surface areas of various catalysts prepared in this investigation are shown in Tab 1. As can be noted from Tab. 1, all samples exhibited reasonably high specific surface areas. Among three combinations synthesized, the $\mathrm{Co}-\mathrm{Ni} / \mathrm{SiO}_{2}$ sample calcined at $475^{\circ} \mathrm{C}$ exhibited a high BET surface area of $191 \mathrm{~m}^{2} \mathrm{~g}^{-1}$. The occurrence of high surface areas in the present investigation could be attributed to the employment of colloidal silica support and also to the preparation method adopted (deposition-precipitation). The co-precipitation of bimetallic precursor over the colloidal silica is expected to yield smaller crystallites of bimetallic oxides on the surface of the $\mathrm{SiO}_{2}$ and exhibit a high specific surface area. However, upon calcination at slightly higher temperature $\left(675^{\circ} \mathrm{C}\right)$ a decrease in the surface area is observed (Tab. 1). This decrease in the surface area is due to sintering of the samples. The surface area of $\mathrm{Cu}-\mathrm{Co} / \mathrm{SiO}_{2}$ catalyst has been very low at $475^{\circ} \mathrm{C}$ compared to others catalysts.

The surface morphology and to assess the dispersion of bimetallic active components over the $\mathrm{SiO}_{2}$ support, SEM investigation was performed on various samples calcined at $475^{\circ} \mathrm{C}$. The representative electron micrographs obtained are presented in Fig. 2. The particle size estimation from SEM data reveals that the average particle size for all the three catalysts $\mathrm{Cu}-\mathrm{Co} / \mathrm{SiO}{ }_{2}$ and $\mathrm{Ni}-\mathrm{Cu} / \mathrm{SiO}_{2}$ and $\mathrm{Co}-\mathrm{Ni} / \mathrm{SiO}_{2}$ is between 10 and $15 \mathrm{~nm}$. Among the three samples investigated, the $\mathrm{Co}-\mathrm{Ni} / \mathrm{SiO}_{2}$ exhibited more porous texture, hence, was also found to exhibit more specific surface area. To get information on the surface composition of the samples, the energy dispersive X-ray microanalysis (EDX) was also performed. As expected, the EDX results revealed the presence of $\mathrm{Si}, \mathrm{O}, \mathrm{Co}, \mathrm{Ni}$ and $\mathrm{Cu}$ elements in the respective samples in appropriate proportions. The quantitative metal loadings detected (wt. \%) in the respective samples are presented in Fig.7. For the purpose of comparison the actual metal loadings deposited during the preparation are also shown in Fig.7. The EDX results corroborate well, within the limit of permissible error, with the actual metal loadings of the samples.

The FT-IR spectra of various bimetallic catalysts prepared in this study were recorded in range of $4000-400 \mathrm{~cm}^{-1}$. Normally, strong bands associated with $-\mathrm{OH}$ stretching vibrations of water and surface hydroxyl groups occur between 3200 and $3700 \mathrm{~cm}^{-1}$. A sharp and strong absorption band in the region $3650-3700 \mathrm{~cm}^{-1}$ was noted in all cases characterizing the presence of hydroxyl groups. Water of hydration usually exhibits one strong band near $3600 \mathrm{~cm}^{-1}$ and one or more sharp bands near $3400 \mathrm{~cm}^{-1}$. Water of hydration can be easily distinguished from hydroxyl groups by the presence of the $\mathrm{H}-\mathrm{O}-\mathrm{H}$ bending motion, which produces a medium band in the region $1600-1650 \mathrm{~cm}^{-1}$. Free water has a strong broad absorption band centered in the region $3200-3400 \mathrm{~cm}^{-1}$. Interestingly, all the three bimetallic samples exhibited fairly similar IR patterns, signifying the predominance of silica IR features in the spectra. The FTIR spectra of catalysts are given in Fig.3.

Aim of employing a support is to achieve an optimal dispersion of the catalytically active components and to stabilize them against sintering. The deposition-precipitation technique takes the advantage of the fact that precipitation onto the preformed carrier needs a lower super saturation than formation of new phases directly from the liquid. The selected support also should be stable under reaction and regeneration conditions and should adversely interact with the solvent, reactants and reaction products. Therefore, the colloidal silica support has 
been advantageously employed in the present investigation. The term colloidal silica refers to a stable dispersion or sols of discrete nanometric particles of amorphous silica, commonly suspended in water with a size of about $7-12 \mathrm{~nm}$ in diameter. Depending on the synthesis conditions, the structure of the colloidal particles may differ from isolated spherical particles to agglomerates of complex structures. Colloidal silica exhibits reasonably high specific surface area ranging between 140 and $345 \mathrm{~m}^{2} \mathrm{~g}^{-1}$. The surface area will be typically constant up to the calcinations temperatures of $475-675^{\circ} \mathrm{C} \mathrm{K}$. However, the porosity is normally lost at temperatures higher than $1200^{\circ} \mathrm{C}$. Since silica is a neutral oxide, there are no strong Bronsted or Lewis acid-base sites on the surface. Untreated silica is totally hydroxylated and the hydroxyl layer is covered with physically adsorbed water (Kinney, Chuang \& Maciel, 1993). The physically adsorbed water can be removed by treating at $300^{\circ} \mathrm{C}$ (Tsyganenko \& Filirnonov, 1973). Thermal treatment of the support leads first to removal of water (dehydration) and then to combination of adjacent hydroxyl groups to form water (dehydroxylation). On silica, the dehydroxylation leads to the formation of surface siloxane bridges (Porta, Dragone, Fierro, Inversi, Jacono \& Moretti, 1992).

The X-ray powder diffractograms of various samples calcined at 475 and $675^{\circ} \mathrm{C}$ are shown in Fig. 4. The oxide mixtures that were observed either contained segregated phases of $\mathrm{NiO}, \mathrm{CuO}$ and $\mathrm{CoO}$ or solid solutions of these combinations. Silica normally exists in any of the three crystallographic forms namely, cristobalite, quartz and tridymite. However, no diffraction patterns pertaining to crystalline $\mathrm{SiO}_{2}$ phase are noted from $\mathrm{XRD}$ results. The absence of $\mathrm{SiO}_{2}$ diffraction patterns indicates that silica is in the amorphous state. In general, the XRD patterns of $475^{\circ} \mathrm{C}$ calcined samples are relatively broad indicating partly amorphous nature of the samples. The XRD patterns of $\mathrm{Co}-\mathrm{Ni} / \mathrm{SiO}_{2}$ sample revealed the presence of a definite compound between cobalt and nickel with the composition $\mathrm{Co}_{1.38} \mathrm{Ni}_{1.61} \mathrm{O}_{4}$. The increase in the intensity of the peaks is due to better crystallization of the sample under the impact of high temperature calcination. The XRD patterns of $\mathrm{Ni}-\mathrm{Cu} / \mathrm{SiO}_{2}$ sample revealed the presence of both $\mathrm{CuO}$ and $\mathrm{NiO}$ phases. With increase in calcination temperature from 475 and $675^{\circ} \mathrm{C}$ and increase in the intensity of the lines due to better crystallization of these phases was observed. However, as reported by Davies et.al, the formation of tetragonal or orthorhombic phases is not found probably due to a different preparation method adopted and the lower calcination temperature has studied (Maki-Arvela, Tiaine, Lindblad, Demirkan, Kumar, Sjoholm, Ollonqvist, Vayrynen, Salmil, \&. Murzin, 2003).

The XRD profiles of $\mathrm{Cu}-\mathrm{Co} / \mathrm{SiO}_{2}$ sample calcined at $475^{\circ} \mathrm{C}$ revealed the formation of a non-stoichiometric cobalt-copper-oxide solid solution $\mathrm{Cu}_{0.76} \mathrm{Co}_{2.24} \mathrm{O}_{4}$. This solid solution of general formula $\mathrm{Cu}_{\mathrm{x}} \mathrm{Co}_{3-\mathrm{x}} \mathrm{O}_{3}$ exhibits spinel structure formed by partial migration of copper into the spinel structure of $\mathrm{Co}_{3} \mathrm{O}_{4}$ compound. Although the standard XRD patterns of $\mathrm{Cu}_{\mathrm{x}} \mathrm{Co}_{3-\mathrm{x}} \mathrm{O}_{4}$ are very similar to that of $\mathrm{Co}_{3} \mathrm{O}_{4}$, the presence of these $\mathrm{Cu}-\mathrm{Co}$ oxide solid solutions have been identified in the literature by using the differences in the diffraction patterns from the 311, 511 and 111 planes, corresponding to the differences in d values of around $0.01 \mathrm{~A}^{\circ}$ ( $\mathrm{Li}$, Dai \& Peng, 1990). Porta et al. 1992 investigated $\mathrm{Cu}$ - and Co-mixed oxides of different atomic ratios and observed the presence $\mathrm{Cu}_{\mathrm{x}} \mathrm{Co}_{3-\mathrm{x}} \mathrm{O}_{4}$ and $\mathrm{CuO}$ for an atomic ratio of 50:50. They suggested that a change of $0.005 \mathrm{~A}^{\circ}$ in the $\mathrm{a}_{0}$ cell parameter of the $\mathrm{Co}_{3} \mathrm{O}_{4}$ phase indicates mixed oxide formation. The formation of a $\mathrm{Cu}-\mathrm{Co}$ spinel is very difficult and reveals a lower thermal stability. $\mathrm{Li}$ et al. 1990 synthesized $\mathrm{Cu}-\mathrm{Co}$ mixed oxides with a $\mathrm{Cu} / \mathrm{Co}$ atomic ratio of $0.25-1.0$ and observed that the $\mathrm{Cu}-\mathrm{Co}$ spinel is formed above $588 \mathrm{~K}$ and stable up to $623 \mathrm{~K} \mathrm{for} \mathrm{Cu} / \mathrm{Co}<1$. For the sample with $\mathrm{Cu} / \mathrm{Co}=1$, a facile transformation of $\mathrm{Cu}-\mathrm{Co}$ spinel into $\mathrm{CuO}$ and $\mathrm{Co}_{3} \mathrm{O}_{4}$ was noted. In the present study with increase in calcination temperature from $475-675^{\circ} \mathrm{C}$, in addition to the existence of $\mathrm{Cu}_{0.76}$ $\mathrm{Co}_{2.24} \mathrm{O}_{4}$ phase, emergence of a new crystalline $\mathrm{CuO}$ phase was noted. This observation is in accordance with the earlier cited literature. With increase in calcination temperature a better crystallization of various phases in the sample is a known phenomenon, which clearly signifies the influence of calcinations temperature on the crystallization and formation of new phases in line with literature. It is a reported fact that after reduction and passivation of the $\mathrm{Cu}-\mathrm{Co}$ solid solution the XRD analysis revealed disappearance of the mixed oxide with the formation of a metallic phase with fcc structure, whose lattice values $(a=b=c=0.3594 \mathrm{~nm}$ ) are intermediate of $\mathrm{Cu}(\mathrm{a}=0.3615 \mathrm{~nm})$ and $\mathrm{Co}(\mathrm{a}=0.3545 \mathrm{~nm})$ metallic phases confirming formation of a $\mathrm{Cu}-\mathrm{Co}$ alloy system. This was also substantiated by IR spectroscopy (BaiJliard-Letoumel, Cobo, Mirodotos, Primet \& Dalmon, 1989) of the $\mathrm{Cu}-\mathrm{Co} / \mathrm{Al}_{2} \mathrm{O}_{3}$ and transmission electron microscopy of the $\mathrm{Cu}-\mathrm{Co} / \mathrm{SiO}_{2}$ catalysts. Therefore, it can be concluded that the alloy formation is favoured by the presence of $\mathrm{Cu}_{\mathrm{x}} \mathrm{Co}_{3-\mathrm{x}} \mathrm{O}_{4}$ phase in the precursor.

\subsection{Catalytic reaction}

Liquid phase hydrogenation of citral can be observed in the scheme of Fig. 1, citral can give rise to a large variety of products depending on which double bond is attacked by hydrogen. The three main primary hydrogenation products obtained by the reaction of one of the conjugated double bonds are citronellal (saturated aldehydes), geraniol and nerol (unsaturated alcohols). These compounds still have two double bonds and so further hydrogenation can give citronellol. In the hydrogenation of citral, both activity and selectivity were 
studied to assess those factors which might lead to higher active and improved selectivity to prepared bimetallic silica supported catalysts. The data are shown in Tab. 1. It can be observed that all cases in the present investigation, the reaction produces unsaturated alcohol (geraniol and nerol), selectively in three series of catalysts calcined at $475^{\circ} \mathrm{C}$ and $675^{\circ} \mathrm{C}$ temperature with various conditions of temperature, pressure, agitation rpm and catalyst load.

\subsubsection{Effect of pressure}

The hydrogenation reaction was carried out at hydrogen pressures ranging 1 to 6 bars while maintaining a constant temperature and initial citral concentration. The results showed that increasing the hydrogen pressure, resulted in increase in the rate of conversion of citral in Fig. 5 indicates that the rate of reaction is directly proportional to the hydrogen pressure, effectily exhibiting a first order dependency on hydrogen. The reaction selective and conversion of unsaturated alcohols (geraniol and nerol) under such condition of difference range of hydrogen pressure. The rate of reaction has been studied with higher selective of citral hydrogenation were obtained with the optimum hydrogenation rate and with catalysts having an optimum specific mental surface area. Among series of bimetallic catalysts higher selective conversion at 4 bar pressure and more favored in $\mathrm{Co}-\mathrm{Ni} / \mathrm{SiO} 2$ catalyst.

\subsubsection{Effect of temperature}

The selectivity of both bimetallic catalysts in shown in Fig. 6, the influence of temperature on the kinetics of the hydrogenation reaction was studied at $60-110^{\circ} \mathrm{C}$ with under such conditions of catalyst loading, $0.2 \% \mathrm{w} / \mathrm{v}$; Citral, $1.67 \mathrm{~mol} \mathrm{dm}^{-3}$; Solvent $3.5 \mathrm{~mol} \mathrm{dm}^{-3}$; Pressure 4 bar; rmp 750. Among the series of catalysts investigated citral hydrogenation higher selective at $90^{\circ} \mathrm{C}$ temperature for conversion in unsaturated alcohol (geraniol and nerol). The hydrogenation selective depends on reaction temperature, increasing temperature the selective hydrogenation of the $\mathrm{C}=\mathrm{O}$ group is much more difficult in the presence of $\mathrm{C}=\mathrm{C}$ bond, because the hydrogenation of the $\mathrm{C}=\mathrm{C}$ bond is thermodynamically more favored.

\subsubsection{Effect of catalyst loading}

From Fig.7, the liquid phase hydrogenation rate increase with catalyst loading especially at lower temperature and have studied at $0.10,0.15,0.2,0.25,0.27$ and $0.30 \% \mathrm{w} / \mathrm{v}$ catalyst loaded with under such conditions. Among the three series of bimetallic catalysts, indicate in Fig. 7 higher (70\%) selective conversion citral to unsaturated alcohols, which in catalyst load is load $0.2 \% \mathrm{w} / \mathrm{v}$. The most favored bimetallic catalyst of Co-Ni/SiO2 calinated at $475^{\circ} \mathrm{C}$.

\subsubsection{Selective conversion of unsaturated alcohol}

The experimental studies of the initial stages of the hydrogenation of citral showed that the selectivity towards geraniol (unsaturated alcohol) increase with increasing conversion, suggesting that a modification of the bimetallic catalyst surface takes place as the reaction proceeds. In order to explain this behavior it is useful to investigate the way the products affect the reaction. From Fig. 8(a), it can be observed in the present investigation, the reaction carried out under conditions of catalyst loading, $0.2 \% \mathrm{w} / \mathrm{v}$; Citral, $1.67 \mathrm{~mol} \mathrm{dm}^{-3}$; Temperature $90^{\circ} \mathrm{C}$; Pressure 4 bar; rpm 750;. Three series of catalysts investigated for liquid phase cital hydrogenation, higher selectivity of $\mathrm{Co}-\mathrm{Ni} / \mathrm{SiO}_{2}$ at $90^{\circ} \mathrm{C}$ temperature for conversion of unsaturated alcohols $(59 \%)$. At that same time $\mathrm{Ni}-\mathrm{Cu} / \mathrm{SiO}_{2}$ is much better than $\mathrm{Cu}-\mathrm{Co} / \mathrm{SiO}_{2}$. The high temperature calcined at $675^{\circ} \mathrm{C}$ bimetallic catalysts, in Fig. 8(b), the rate of reaction and conversion of unsaturated alcohols (geraniol and nerol) was poor compared to calcined at $475^{\circ} \mathrm{C}$ the catalysts. Among the series of bimetallic catalysts investigated higher activity and selectivity is for $\mathrm{Co}-\mathrm{Ni} / \mathrm{SiO}_{2}$ catalyst for or liquid phase hydrogenation of citral towards unsaturated alcohols product.

\section{Conclusions}

The preparation and the characterization of silica supported bimetallic catalysts and their application in liquid phase hydrogenation of citral towards unsaturated alcohols (gerraiol and nerol) has been studied.

- $\quad$ Three series of bimetallic catalysts calcinated at low and high temperature $\left(475^{\circ} \mathrm{C}\right.$ and $\left.675^{\circ} \mathrm{C}\right)$, incorporation of silica support in the colloidal form during deposition precipitation of bimetallic resulted in stable and well formed catalysts with high specific surface area when calcinated at $475^{\circ} \mathrm{C}$. SEM micrograph of the particles was good and particles size are in the nm range (10-14), and show higher surface area for catalysts calcined at $475^{\circ} \mathrm{C}$ than the catalysts calcined at $675^{\circ} \mathrm{C}$.

- The XRD patterns of $\mathrm{Co}-\mathrm{Ni} / \mathrm{SiO}_{2}$, shows the composition of catalyst as $\mathrm{Co}_{1.38} \mathrm{Ni}_{1.61} \mathrm{O}_{4}$. The increase in the intensity of the peaks is due to better crystallization of the sample under the impact of high temperature 
calcinations and $\mathrm{Ni}-\mathrm{Cu} / \mathrm{SiO}_{2}$ catalyst contains, $\mathrm{CuO}$ and $\mathrm{NiO}$ phases. With increase in calcination temperature from $475-675^{\circ} \mathrm{C}$ increase in the intensity of the lines is observed which is due to better crystallization of these phases at high temperature.

- The catalytic activity has been investigated in reaction conditions and compared with the performance of low and high temperature calcinated catalysts. The catalyst $\mathrm{Co}-\mathrm{Ni} / \mathrm{SiO} 2$ calcinated at $475^{\circ} \mathrm{C}$ is found to give the highest selectivity towards unsaturated alcohols.

- It can be observed that for all the cases in the present investigation, the reaction produces unsaturated alcohols (geraniol and nerol), in activity and selectivity for $\mathrm{Co}-\mathrm{Ni} / \mathrm{SiO} 2$ calcined at $475^{\circ} \mathrm{C}$ under conditions of Catalyst loading, $0.2 \% \mathrm{w} / \mathrm{v}$; Citral, $1.67 \mathrm{~mol} \mathrm{dm}^{-3}$; Solvent $3.5 \mathrm{~mol} \mathrm{dm}^{-3}$; Temperature $90^{\circ} \mathrm{C}$; Pressure $4 \mathrm{bar} ; \mathrm{rpm} 750$. Liquid phase citral hydrogenation is most selective for $\mathrm{Co}-\mathrm{Ni} / \mathrm{SiO} 2$. Among these experiments the overall conversion observed is $99 \%$ but selectivity is only $59 \%$ towards unsaturated alcohols (geraniol and nerol). The hydrogenation of citral over these synthesized catalysts indicated that they can be used as the catalysts for other hydrogenation reactions also.

\section{References}

Asedegbega-Nieto, E., Bachiller-Baeza, B., Guerrero-Ruiz, A., Rodriguez-Ramos, I. (2006). Modification of catalytic properties over carbon supported $\mathrm{Ru}-\mathrm{Cu}$ and $\mathrm{Ni}-\mathrm{Cu}$ bimetallics: I. Functional selectivities in citral and cinnamaldehyde hydrogenation. Applied Catalysis A: General, 300 (2), 120-129.

Bachiller-Baeza, B., Rodriguez-Ramos, I., Guerrero-Ruiz, A. (2001). Ruthenium-supported catalysts for the stereoselective hydrogenation of paracetamol to 4-trans-acetamidocyclohexanol: effect of support, metal precursor, and solvent. Applied Catalysis A, General, 205, 227.

Baijun, L., Lianhai, L., Bingchun, W., Tianxi, C., Iwatani, K. (1998). Catalytic Properties and Characterization of Ni-P-B Ultrafine Materials. Applied Catalysis A: General, 171, 117.

BaiJliard-Letoumel, RM., Cobo, AIG, Mirodotos, C., Primet, P., Dalmon, A.I. (1989). Silica supported transition metal-based bimetallic cagtalysis for furfuraldehyde. Catalysis letter, 2, 149.

Bartok M, Molnar A. (1997). In: Patai S (ed) The chemistry of functional groups A3, Wiley Gallezot P, Richard D (1998) Catal Rev, 40:81

Burgener, M., Ferrer, R., Mallat, T., Baiker, A. (2004). Modification of catalytic properties over carbon supported $\mathrm{Ru}-\mathrm{Cu}$ and $\mathrm{Ni}-\mathrm{Cu}$ bimetallics: I. Functional selectivities in citral and cinnamaldehyde hydrogenation. Applied Catalysis A, General, 268(2), 1.

Burgener, M., Wirz, R., Mallat, T., Baiker, A. (2004). Nature of catalyst deactivation during citral hydrogenation: a catalytic and ATR-IR study. Journal of Catalysis, 228 (1), 152.

Coq, B., Figueras, F. (2001). Liquid-phase hydrogenation of maleic anhydride over $\mathrm{Pd} / \mathrm{SiO}_{2}$ : effect of tin on catalytic activity and deactivation. Journal of Molecular Catalysis A: Chemistry, 173 (1-2), 117.

Fouilloux, P. (1998). Heterogeneous Catalysis and Fine Chemicals. Elsevier, Amsterdam, p. 123.

Gallezot P, Richard D. (1998). Catal Rev, 40:81.

Galvagno, S., Donato, A., Neri, G., Pietropaolo, R. (1989). Hydrogenation of $\mathrm{C}=\mathrm{C}$ and $\mathrm{C}=\mathrm{O}$ groups on ruthenium-tin catalysts. Journal of Molecular Catalysis, 49, 223.

Galvagno, S., Milone, C., Donato, A., Neri, G., Pietropaolo, R. (1993). Hydrogenation of substituted aromatic compounds over a ruthenium catalyst. Catalysis Letter, 17 (2), 55.

Kinney, D.R., Chuang, I.S., Maciel, G.E. (1993). NMR Studies of Interfacial Phenomena. Journal of American Chernical Society. 115, 6786.

Kulkarni, G.U., Sankar, G., Rao, C.N.R. (1991). An in situ EXAFS investigation of bimetallic $\mathrm{Cu}---\mathrm{Ni} / \gamma-\mathrm{Al}_{2} \mathrm{O}_{3}$ catalysts. Journal of Catalysis, 131(2), 491.

Lashdaf, M., Hase, A., Kauppinen, E., Krause, A.O.I. (2006). Modification of catalytic properties over carbon supported $\mathrm{Ru}-\mathrm{Cu}$ and $\mathrm{Ni}-\mathrm{Cu}$ bimetallics: I. Functional selectivities in citral and cinnamaldehyde hydrogenation. Journal of applied Catalysis, 300(2)12.

Lashdaf, M., Lahtinen, J., Lindblad, M., Venalainen, T., Krause, A.O.I. Platinum on carbon nanofibers as catalyst for cinnamaldehyde hydrogenation. Applied Catalysis A: General, 276 (1-2), 129.

Lee, S.-P., Chen, Y.-w. (1999). Effects of Preparation on the Catalytic Properties of Ni-P-B Ultrafine Materials. Industrial \&. Engineering. Chemical Research, 38, 2548. 
Li, G. -H., Dai, L.-Z., Lu, D.-D., Peng, S.-Y. (1990). VUV-UV Photoluminescence Spectra of Strontium Orthophosphate Doped with Rare Earth Ions. Journal of Solid State Chemistry, 89, 167.

Luo, H., Li, H., Zhuang, L. (2001). Preparation and catalytic properties of a bimetallic Sn-Pt complex in the supercages of $\mathrm{NaY}$ zeolite by use of surface organometallic chemistry.Chemistry. Letter, 5, 404.

Maki-Arvela, P., Tiaine,L.P., Lindblad, M., Demirkan, K., Kumar, N., Sjoholm, R., Ollonqvist, T., Vayrynen, J., Salmil, T., Murzin, D.Yu. (2003). Liquid-phase hydrogenation of citral for production of citronellol: catalyst selection. Applied Catalysis A: General, 241, 271-288.

Malathi, R., Viswanath R.P. (2001). Citral hydrogenation on supported Platinum catalysts. Applied Catalysis A: General, 208 (1-2), 323.

Mali-Arvela, P., Tiainen, L.P., Lindblad, M., Kumar, N., Sjoholm, R., Ollonqvist, T., Vayrnen, J., Salmi, T., Murzin, D. Yu. (2003). High-active nickel catalyst of $\mathrm{NiB} / \mathrm{SiO}_{2}$ for citral hydrogenation at low temperature. Applied Catalysis A: General, 241, 271-288.

Neri, G., Mercadante, L., Donato, A., Visco, A.M., Galvagno, S. (1994). Influence of Ru precursor, support and solvent in the hydrogenation of citral over ruthenium catalysts. Cataysis Letter, 29, 379.

Ponec, Y. (2001). Study of $\mathrm{CO}$ chemisorption on graphite-supported $\mathrm{Ru}-\mathrm{Cu}$ and $\mathrm{Ni}-\mathrm{Cu}$ bimetallic catalysts. Applied Catalysis A: General, 222, 31.

Porta, P., Dragone, R., Fierro, G., Inversi, M.. Lo Jacono, Moretti, G. (1992). Thermal activation of Copper nitrates. Journal Chemical Society Faraday Transmitanse, 86, 311.

Reddy, B.M., Ganesh, I., Khan, A. (2004). Structural characterization and dehydration activity of $\mathrm{CeO}_{2}-\mathrm{SiO}_{2}$ and $\mathrm{CeO}_{2}-\mathrm{ZrO}_{2}$ mixed oxides prepared by a rapid microwave-assisted combustion synthesis method. Journal of Molecular Catalysis A: Chemistry, 223, 295.

Richard, D., Ockelford, J., Giroir-Fendler, A., Gallezot, P. (1989). Selective Liquid-Phase Hydrogenation of Citral over Supported Palladium, Catalysis Letter, 353.

Savargaonkar, N., Khanra, B.C., Pruski, M., King, T.S. (1996). Influence of Hydrogen Chemisorption on the Surface Composition of Pt-Rh/ $\mathrm{Al}_{2} \mathrm{O}_{3}$ Catalysts. Journal of Catalysis, 162 (2), 277.

Singh, U.K., Vannice, M.A. (2000). Pd catalyzed completely selective hydrogenation of conjucated and isolated $\mathrm{C}=\mathrm{C}$ of citral in supercritical carbon dioxide. Journal of Molecular Catalysis A: Chemistry, 163, 233.

Singh, U.K., Vannice, M.A. (2001). Liquid-Phase Citral Hydrogenation over $\mathrm{SiO}_{2}$-Supported Group VIII Metals. Journal of Catalysis, 199 (1), 73.

Smith GV, Notheisz F. (1999). Heterogeneous catalysis in organicchemistry, Acad. Press; Sheldon-Bekkum (2001) Fine chemicals through heterogeneous catalysis, Wiley-VCH, p 365.

Tiainen, J L.-P., Maki-Arvela, P., Salmi, T. (1999). Modelling of citral hydrogenation kinetics on an $\mathrm{Ni} / \mathrm{Al}_{2} \mathrm{O}_{3}$ catalyst. Catalysis Today, 48 (1), 57.

Tsyganenko, A.A., Filirnonov, Y.N. (1973). Morphology and Surface Properties of Boehmite ( $\gamma$-AlOOH): A Density Functional Theory Study. Journal of Molecular Structure, 19, 579.

Zhu, Y., Liu, S., Jaenicke, S., Chuah, G.. (2004). Zirconia catalysts in Meerwein-Ponndorf-Verley reduction of citral. Catalysis Today, 97(4), 249-255. 
Table 1. Various bimetallic (Co-Ni; $\mathrm{Ni}-\mathrm{Cu}$ and $\mathrm{Cu}-\mathrm{Co}$ ) silica supported catalysts calcined at 475 and $675^{\circ} \mathrm{C}, \mathrm{BET}$ SA measurements of and actual metal loading, metal loadings from EDX analysis, XRD phase observed

\begin{tabular}{|c|c|c|c|c|c|c|c|c|c|}
\hline \multirow{2}{*}{$\begin{array}{l}\text { Bimetallic } \\
\text { catalyst }\end{array}$} & \multirow{2}{*}{$\begin{array}{l}\text { Calcination } \\
\text { Temp. }\left({ }^{\circ} \mathrm{C}\right)\end{array}$} & \multirow{2}{*}{$\begin{array}{l}\text { XRD phases } \\
\text { Identified }\end{array}$} & \multicolumn{3}{|c|}{$\begin{array}{l}\text { Actual metal loading } \\
(\mathrm{wt} \%)\end{array}$} & \multicolumn{3}{|c|}{$\begin{array}{l}\text { Metal loading from } \\
\text { EDX analysis (wt\%) }\end{array}$} & \multirow{2}{*}{$\begin{array}{c}\text { BET } \\
\text { SA } \\
\left(\mathrm{m}^{2} \mathrm{~g}^{-1}\right)\end{array}$} \\
\hline & & & Co & $\mathbf{N i}$ & $\mathrm{Cu}$ & Co & $\mathbf{N i}$ & $\mathrm{Cu}$ & \\
\hline \multirow{2}{*}{$\mathrm{Co}-\mathrm{Ni} / \mathrm{SiO}_{2}$} & 475 & $\mathrm{Co}_{1.38} \mathrm{Ni}_{1.61} \mathrm{O}_{4}$ & 10 & 10 & 0 & 9.74 & 9.32 & 0 & 191 \\
\hline & 675 & $\mathrm{Co}_{1.38} \mathrm{Ni}_{1.61} \mathrm{O}_{4}$ & 10.23 & 9.77 & 0 & 9.88 & 9.41 & 0 & 163 \\
\hline \multirow{2}{*}{$\mathrm{Ni}-\mathrm{Cu} / \mathrm{SiO}_{2}$} & 475 & $\mathrm{NiO} ; \mathrm{CuO}$ & 0 & 9.7 & 10.3 & 0 & 11.42 & 12.41 & 158 \\
\hline & 675 & $\mathrm{NiO} ; \mathrm{CuO}$ & 0 & 9.81 & 10.19 & 0 & 11.09 & 12.58 & 131 \\
\hline \multirow{2}{*}{$\mathrm{Cu}-\mathrm{Co} / \mathrm{SiO}_{2}$} & 475 & $\mathrm{Cu}_{0.75} \mathrm{Co}_{2.25} \mathrm{O}_{4}$ & 10.26 & 0 & 9.64 & 10.42 & 0 & 11.32 & 165 \\
\hline & 675 & $\mathrm{Cu}_{0.76} \mathrm{Co}_{2.25} \mathrm{O}_{4} ; \mathrm{CuO}$ & 10.83 & 0 & 9.17 & 10.52 & 0 & 11.13 & 125 \\
\hline
\end{tabular}

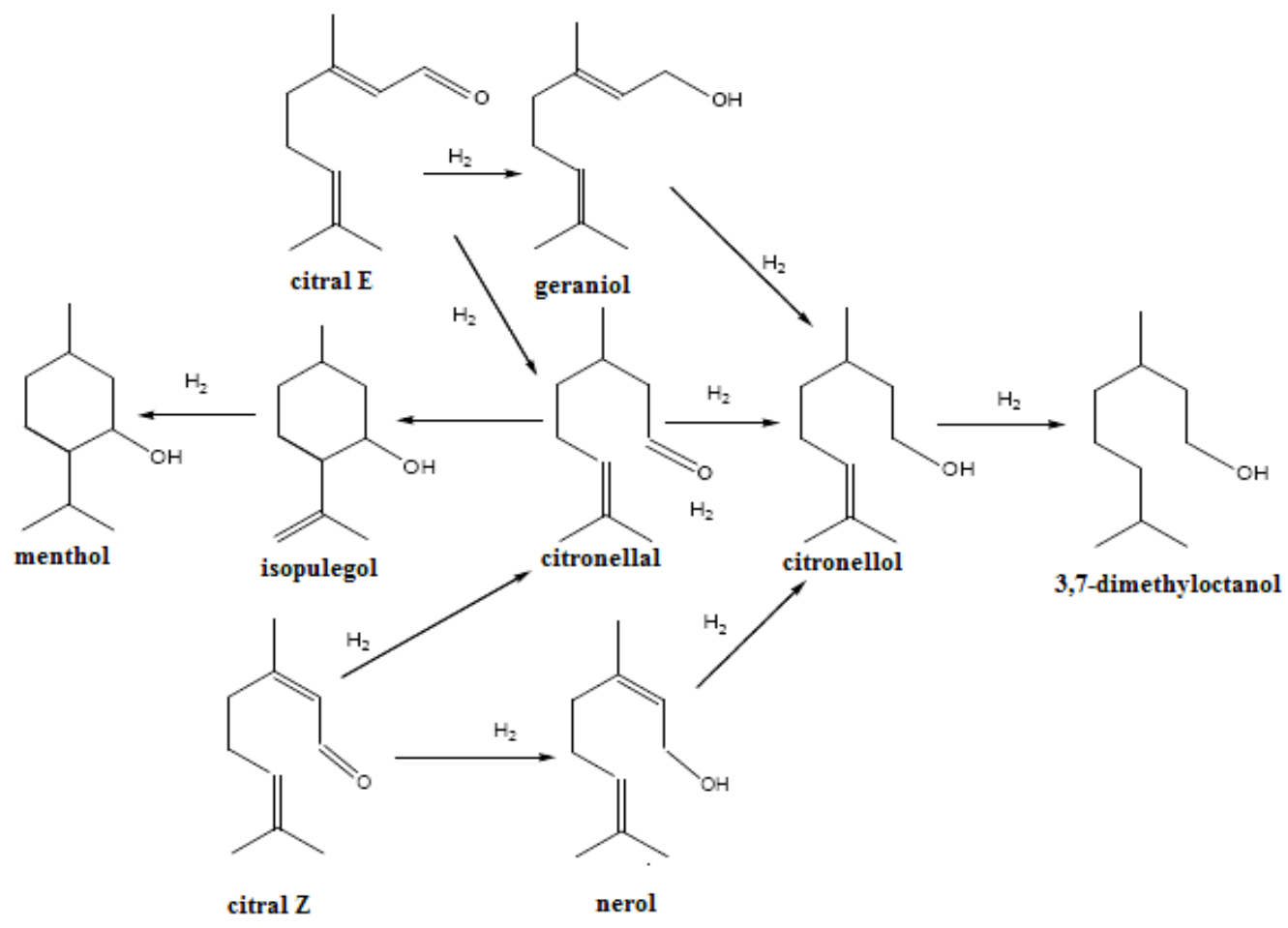

Figure 1. Scheme of Citral hydrogenation 

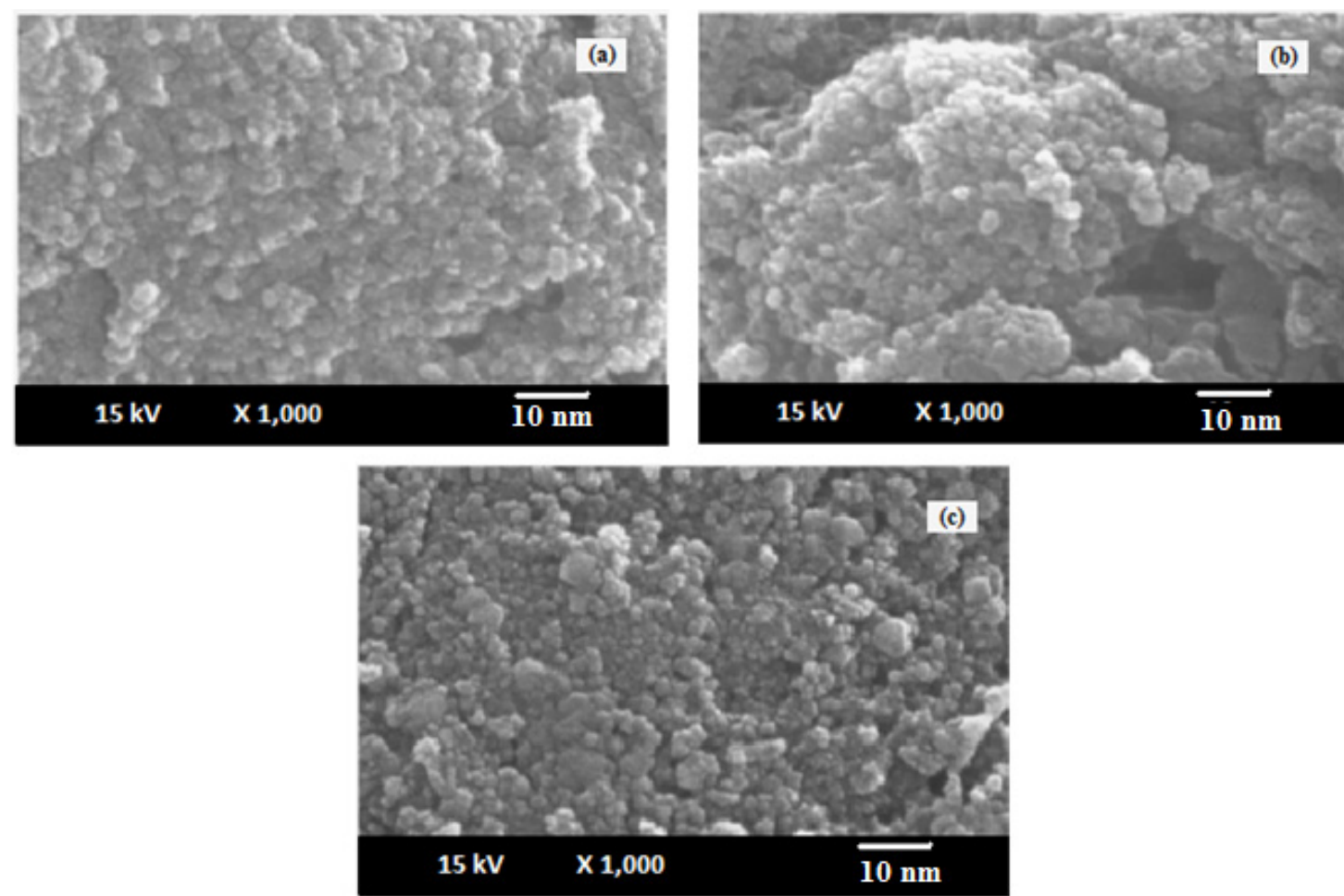

Figure 2. SEM micrographs of (a) $\mathrm{Co}-\mathrm{Ni} / \mathrm{SiO}_{2}$; (b) $\mathrm{Ni}-\mathrm{Cu} / \mathrm{SiO}_{2}$; ( c) $\mathrm{Cu}-\mathrm{Co} / \mathrm{SiO}_{2}$ calcined at $675^{\circ} \mathrm{C}$

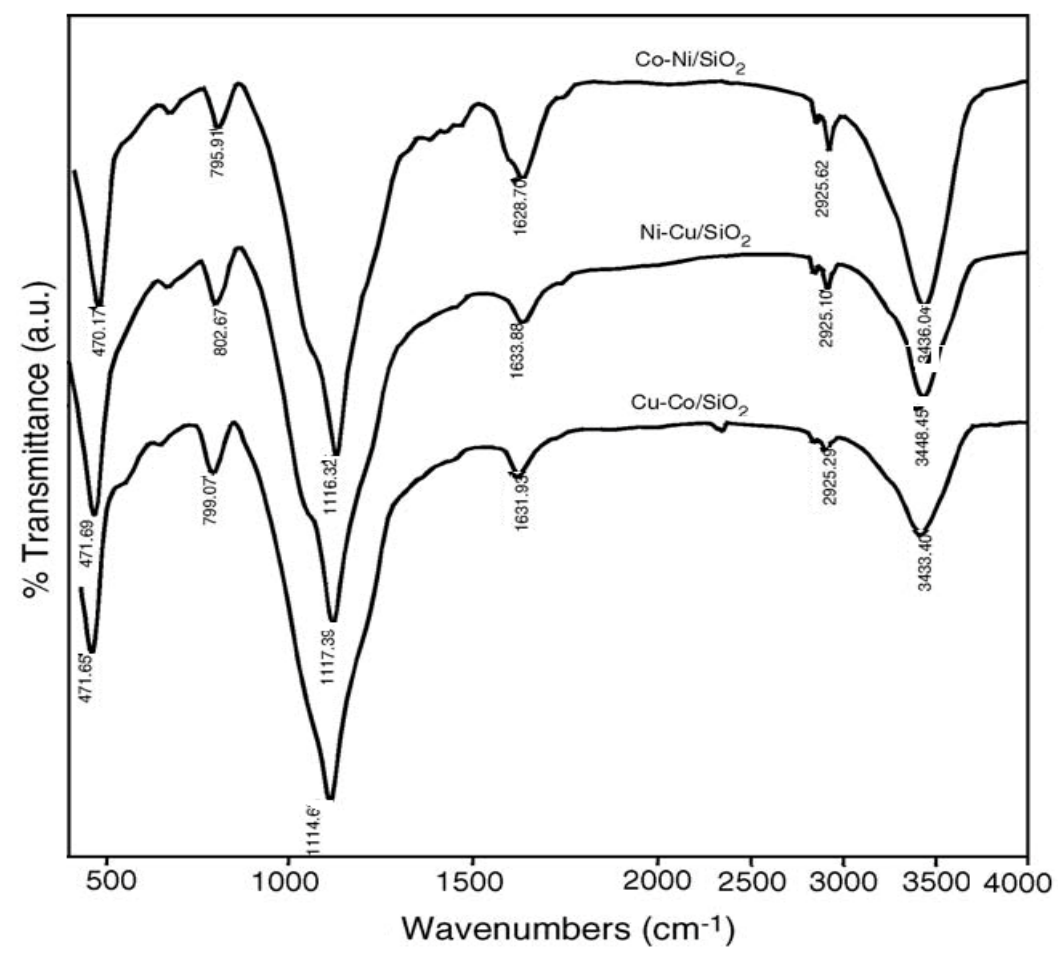

Figure 3. FT-IT spectra of (a) $\mathrm{Co}-\mathrm{Ni} / \mathrm{SiO}_{2}$; (b) $\mathrm{Ni}-\mathrm{Cu} / \mathrm{SiO}_{2}$; (c) $\mathrm{Cu}-\mathrm{Co} / \mathrm{SiO}_{2}$ Samples calcinated at $475^{\circ} \mathrm{C}$ 


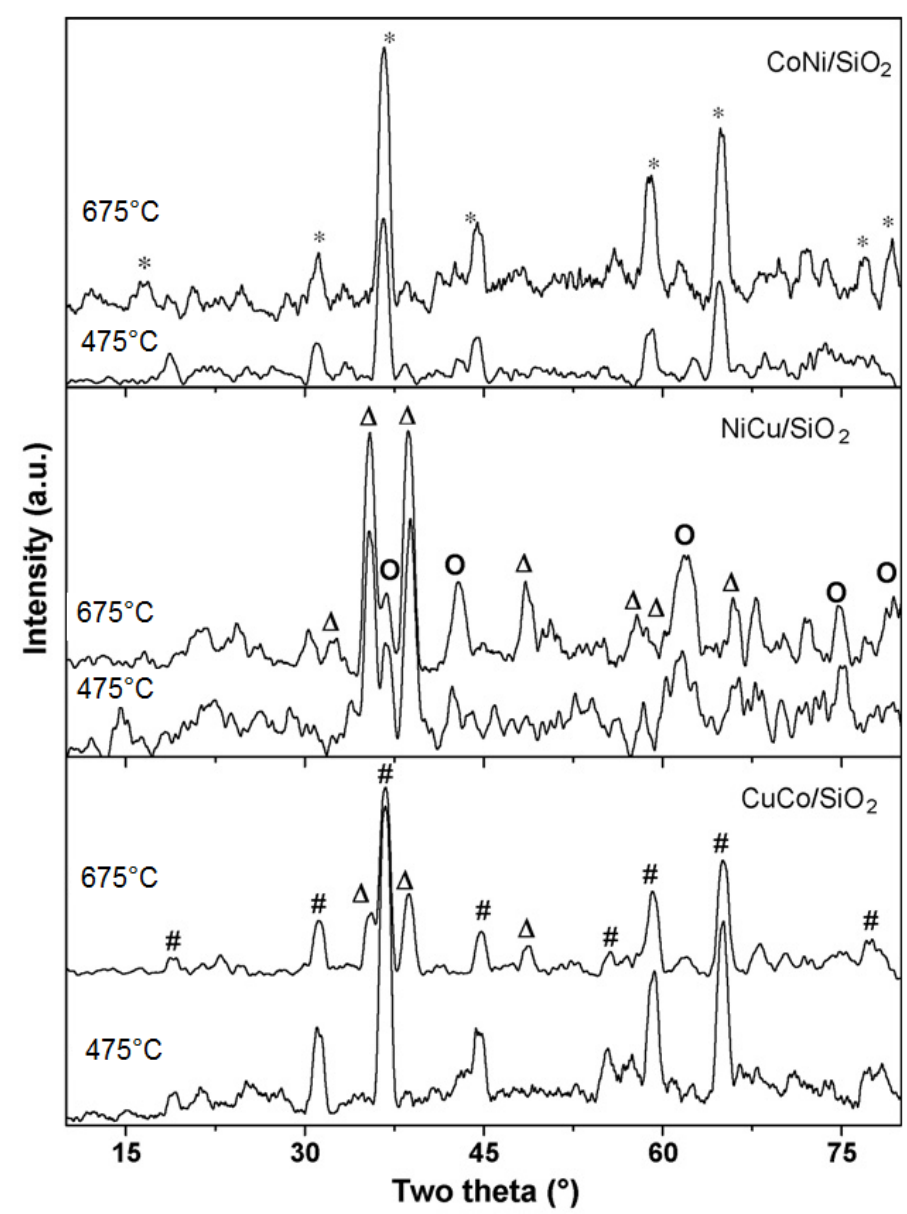

Figure 4. X-ray diffraction patterns of various bimetallic catalysts calcined at 475 and $675^{\circ} \mathrm{C},\left({ }^{*}\right)$ lines due to $\mathrm{Co}_{1.38} \mathrm{Ni}_{1.61} \mathrm{O}_{4}$ phase; $(\Delta)$ lines due to $\mathrm{CuO}$ phase; $(\mathrm{O})$ lines due to $\mathrm{NiO}$ phase; $(\#)$ line due to $\mathrm{Cu}_{0.75} \mathrm{Co}_{2.25} \mathrm{O}_{4}$ phase 


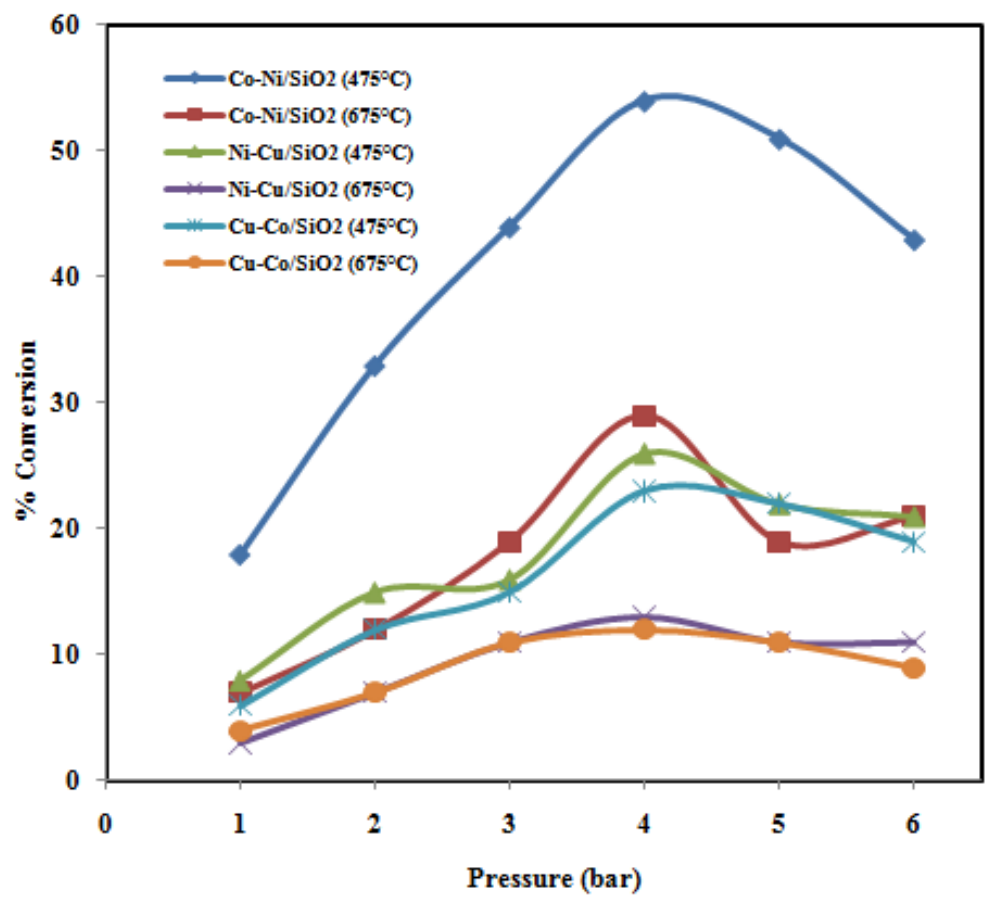

Figure 5. Percentage of conversions against pressure for Bimetallic supported catalysts calinated at 475 and $675^{\circ} \mathrm{C}^{\#}$

${ }^{\#}$ The selectivity is $100 \%$ towards unsaturated alcohols (geraniol and neraol) is all the cases. Conditions: Catalyst loading, $0.2 \% \mathrm{w} / \mathrm{v}$; Citral, $1.67 \mathrm{~mol} \mathrm{dm}^{-3}$; Solvent $3.5 \mathrm{~mol} \mathrm{dm}^{-3}$; Temperature $363 \mathrm{~K}$; rpm 750

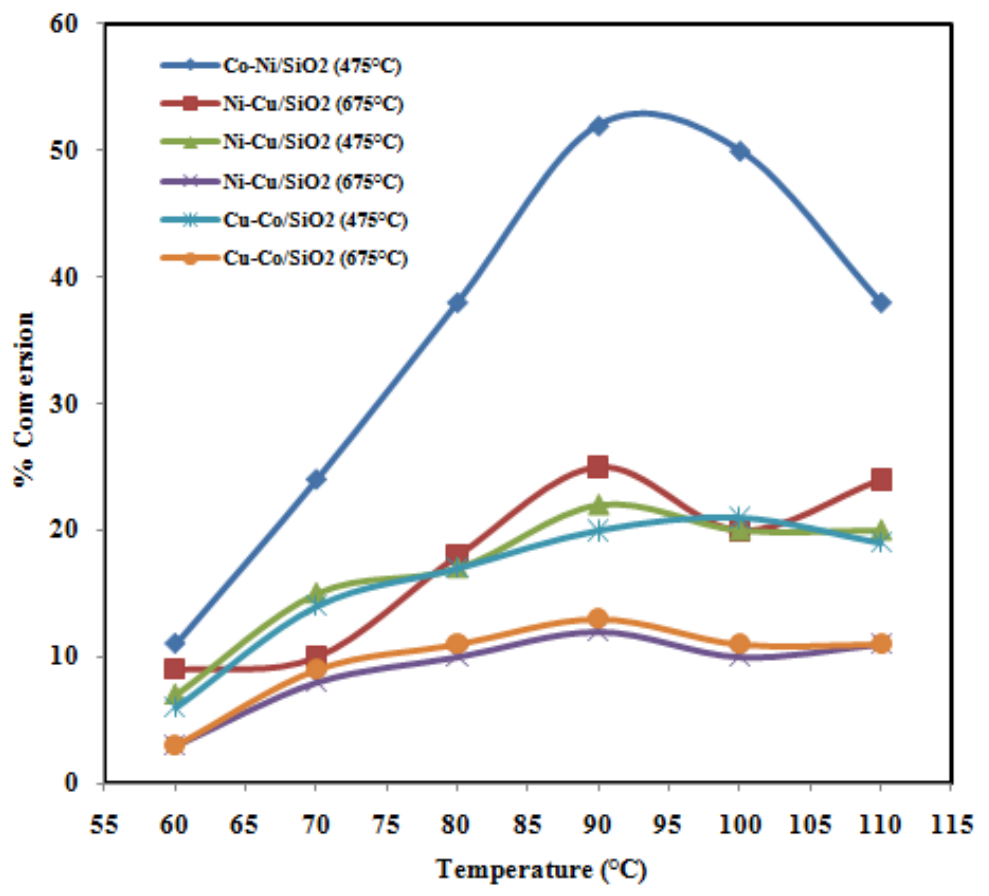

Figure 6. Percentage conversions against temperature for Bimetallic supported catalysts calcined at 475 and $675^{\circ} \mathrm{C}^{\#}$

${ }^{\#}$ The selectivity is $100 \%$ towards unsaturated alcohols (geraniol and neraol) is all the cases. Conditions: Catalyst loading, $0.2 \% \mathrm{w} / \mathrm{v}$; Citral, $1.67 \mathrm{~mol} \mathrm{dm}^{-3}$; Solvent $3.5 \mathrm{~mol} \mathrm{dm}^{-3}$; Pressure 4 bar; rpm 750 . 


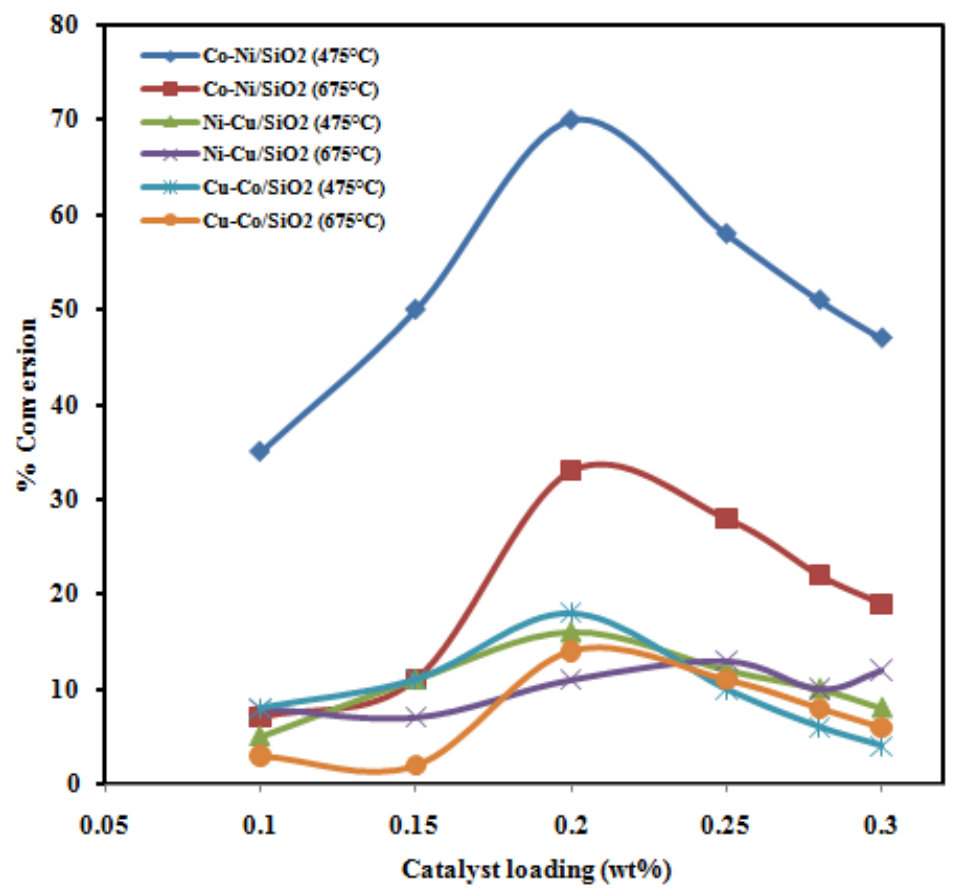

Figure 7. Percentage conversion against Catalyst loading for Bimetallic supported catalysts calinated 475 and $675^{\circ} \mathrm{C}^{\#}$

${ }^{\#}$ The selectivity is $100 \%$ towards unsaturated alcohols (geraniol and neraol) is all the cases. Conditions: Citral, $1.67 \mathrm{~mol} \mathrm{dm}^{-3}$; Solvent 3.5 $\mathrm{mol} \mathrm{dm}^{-3}$; Temperature $363 \mathrm{~K}$; Pressure 4 bar; rpm 750.
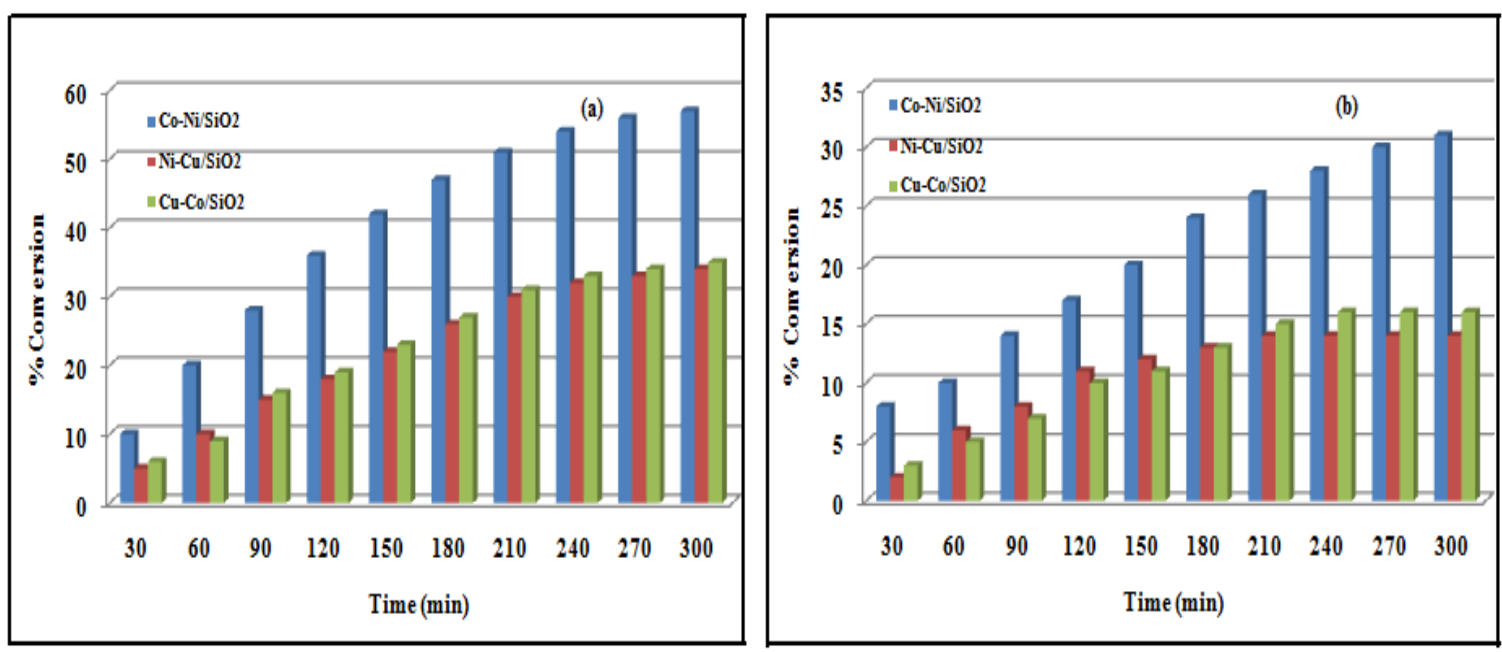

Figure 8. Percentage conversion against Time for Bimetallic silica supported catalysts calcined at (a) $475^{\circ} \mathrm{C}$ (b) $675^{\circ} \mathrm{C}$; Temperature, $90^{\circ} \mathrm{CK}$; Pressure 4 bar ; Agitation rpm,750; Catalyst loading, $0.2 \% \mathrm{w} / \mathrm{v}$; Citral, $1.67 \mathrm{~mol}$ $\mathrm{dm}^{-3}$; Solvent $3.5 \mathrm{~mol} \mathrm{dm}^{-3}$ 